\title{
Characterization of conceptus-produced goat interferon $\tau$ and analysis of its temporal and cellular distribution during early pregnancy
}

\author{
M. Guillomot ${ }^{\mathrm{I}}$, P. Reinaud ${ }^{2}$, C. La Bonnardière ${ }^{3}$ and G. Charpigny ${ }^{2}$ \\ ${ }^{1}$ Unite de Recherche Associee, INRA-CNRS 1291; ${ }^{2}$ Unite d'Endocrinologie de l'Embryon, \\ Station de Physiologie Animale, INRA; and ${ }^{3}$ Unité Virologie et Immunologie Moléculaire, INRA, \\ 78352 Jouy-en-Josas, France
}

\begin{abstract}
Two proteins ( 17 and $22-24 \mathrm{kDa}$ ) produced by day 17 goat conceptuses were purified from in vitro culture media. Analysis of their N-terminal amino acid sequences and of their antiviral activity confirmed that both proteins belonged to the interferon tau family characteristic of ruminant conceptuses. The two molecules were glycosylated $(22-24 \mathrm{kDa})$ or nonglycosylated ( $17 \mathrm{kDa}$ ) isoforms of the same protein. The time course of secretion was plotted and immunoblotting of the protein contents of uterine flushings from day 13 to day 21 of pregnancy was performed. The nonglycosylated isoform $(17 \mathrm{kDa})$ was first detected on day 16; both isoforms were present at day 17 and, thereafter during pregnancy, the two proteins were not present in uterine flushings. Immunohistochemistry was used to show that the goat interferon tau was present in the trophoblastic cells as early as day 14 and until day 17. However, immunostaining was not uniform along the conceptus; labelling was greater at the abembryonic pole than at the embryonic pole. By day 18 , as implantation proceeded, goat interferon tau was no longer detected. These results confirmed that the goat conceptus secretes interferon tau during the period of maternal recognition of pregnancy but its rapid decrease suggests that other factors need to be present by day 18 to take over its role in the maintenance of luteal function.
\end{abstract}

Introduction

In ruminants, secretion of interferon tau (IFN- $\tau$ ) by the conceptus is responsible for the maintenance of corpus luteum function and establishment of pregnancy (Stewart, 1990; Bazer et al., 1996). Bovine (bIFN- $\tau$ ) and ovine IFN- $\tau$ (olFN- $\tau)$ have been purified and are well characterized (Roberts et al., 1992). Less information is available concerning goat IFN- $\tau$ (cIFN- $\tau$ ). During the period of maternal recognition of pregnancy, goat conceptuses collected from day 16 to day 21 produce a family of proteins that share biochemical charcteristics with, and are immunologically related to, the ovine and bovine IFN- $\tau$ (Gnatek et al., 1989; Baumbach et al., 1990). Similar mRNA to that encoding for oIFN- $\tau$ is expressed by goat day 17 conceptus (Charlier et al., 1989) and a gene encoding cIFN- $\tau$ has been cloned (Leaman and Roberts, 1992). One of the $17 \mathrm{kDa}$ isoforms of cIFN- $\tau$ has been purified and has been shown to present the immunological properties of IFNs (Newton $e$ al., 1996). Experimental injections of recombinant olFN- $\tau$ have provided evidence that maintenance of corpus luteum function in goats is mediated by IFN- $\tau$ as has been reported in sheep and cattle (Homeida and AI-Afaleq, 1994; Newton et al., 1996). The aim of the present study was to purify goat IFN- $\tau$ and to follow its secretion in vivo and its cellular distribution during the peri-implantation period.

Received 5 June 1997

\section{Material and Methods}

\section{Animals and tissue sampling}

All procedures relating to the care and use of animals were approved by the French Ministry of Agriculture according to the French regulations (guidelines 19/04/1988). Goats used in this study were from the Saanen or Alpine breeds. Oestrous cycles were synchronized by intravaginal sponges containing $45 \mathrm{mg} 6 \alpha$-methyl-17 $\alpha$ acetoxyprogesterone for 11 days. Two days before the day of sponge withdrawal, the goats received 400 iu pregnant mares' serum gonadotrophin (PMSG) and $0.2 \mathrm{ml}$ Oestrumate (Intervet, Angers). Oestrus was detected $36 \mathrm{~h}$ after withdrawal of the sponge. The goats were mated at oestrus (day 0) and killed at days 10-21 after breeding. Conceptuses were flushed from the uterine horns with sterile PBS, and were either cultured (day 17 conceptuses only) or processed for immunocytochemistry. By days 18-21, pieces of endometrial tissues with adhering trophoblast were dissected and fixed for immunohistochemistry. Tissues were fixed in $4 \%$ $(\mathrm{w} / \mathrm{v})$ phosphate-buffered paraformaldehyde and processed for routine embedding in paraffin wax.

\section{In vitro culture of conceptuses}

Day 17 conceptuses were cultured according to the method described by Charpigny et al. (1988). Briefly, conceptuses were 


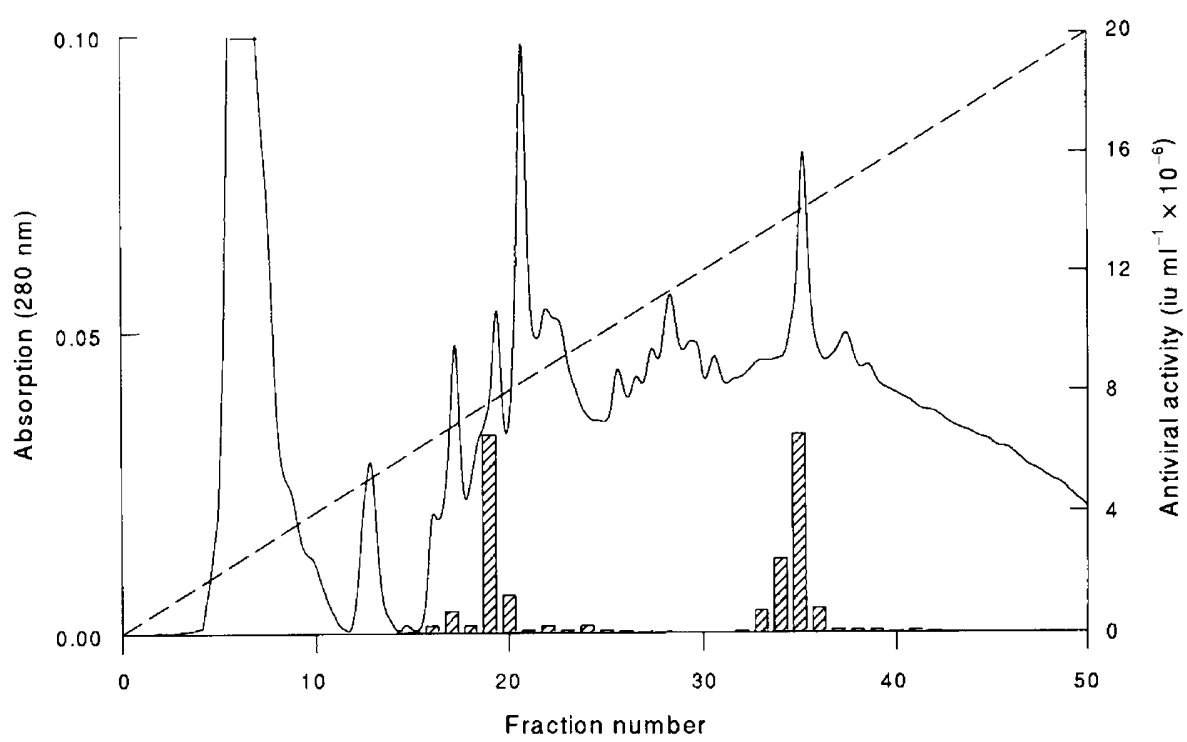

Fig. 1. Elution profile of goat day 17 conceptus culture media after anion-exchange chromatography and the pattern of antiviral activity in the eluted fractions (『). The dashed line represents the linear gradient from 0 to $0.5 \mathrm{~mol} \mathrm{KCl}^{-1}$.

transferred to $100 \mathrm{~mm}$ Petri dishes (one conceptus per dish) containing $10 \mathrm{ml}$ Earle's minimum essential medium (MEM) that was supplemented with $0.05 \%(\mathrm{w} / \mathrm{v})$ polyvinyl-pyrolidone (PVP), ITS (providing $5 \mathrm{mg}$ bovine insulin $1^{-1}, 5 \mathrm{mg}$ human transferrin $\mathrm{l}^{-1}$ and $5 \mathrm{mg}$ sodium selenite $\mathrm{l}^{-1}$, Sigma, Saint Quentin, Fallavier), aprotinin $\left(5 \times 10^{6} \mathrm{iu}^{-1}\right.$; Choay Lab., Ris, Orangis), penicillin $\left(2 \times 10^{5} \mathrm{iu} \mathrm{I}^{-1}\right)$, streptomycin $\left(200 \mathrm{mg} \mathrm{l}^{-1}\right)$ and nystatin $\left(50 \mathrm{mg} \mathrm{l}^{-1}\right)$. Culture was performed on a rocking platform in a controlled atmosphere chamber flushed with $5 \%$ $\mathrm{CO}_{2}$. Media were changed every $24 \mathrm{~h}$ for 3-5 days. All the culture media were centrifuged ( $10000 \mathrm{~g}$ at $4^{\circ} \mathrm{C}$ for $15 \mathrm{~min}$ ), concentrated by ultrafiltration, dialysed (molecular mass cut-off $10 \mathrm{kDa}$ ) against $50 \mathrm{mmol}$ Tris $-\mathrm{HCl} \mathrm{l}^{-1}, \mathrm{pH} 8$ and stored at $-20^{\circ} \mathrm{C}$ until use.

\section{Purification of the goat interferon $\tau$}

Goat interferon $\tau$ was purified from dialysed culture media with a two step HPLC procedure on a Waters system model $600 \mathrm{E}$ (Waters Associates, St Quentin). First, an anion exchange separation was carried out on a TSK-DEAE-5PW column $(21.5 \mathrm{~mm} \times 150 \mathrm{~mm})$. Proteins were eluted at $4 \mathrm{ml} \mathrm{min}^{-1}$ with a $100 \mathrm{~min}$ linear gradient of $0.5 \mathrm{~mol} \mathrm{KCl} \mathrm{1^{-1 }}$ in $50 \mathrm{mmol}$ Tris- $\mathrm{HCl} \mathrm{I}{ }^{-1}, \mathrm{pH}$ 8.0. Fractions were collected every $2 \mathrm{~min}$, starting with a blank fraction numbered 1. Second, fractions positive for antiviral activity and showing a crossreactivity with anti-ovine IFN- $\tau$ (see below) were subjected to chromatography onto a Vydac C4 reverse phase column $(4.6 \mathrm{~mm} \times 150 \mathrm{~mm})$. Proteins were eluted at $0.75 \mathrm{ml} \mathrm{min} \mathrm{m}^{-1}$ using a gradient from trifluoroacetic acid in water (0.1:99.9) (solvent A) and trifluoroacetic acid in acetonitrile (0.1:99.9) (solvent B) as follows: linear gradient from $10 \% \mathrm{~B}$ to $35 \% \mathrm{~B}$ in $24 \mathrm{~min} ; 24-40 \mathrm{~min}$ isocratic elution at $35 \% \mathrm{~B} ; 40-60 \mathrm{~min}$, linear gradient to $50 \% \mathrm{~B} ; 60-80 \mathrm{~min}$, linear gradient to $90 \% \mathrm{~B}$. Proteins were monitored by UV absorbance at $280 \mathrm{~nm}$ for both ion exchange and reverse phase chromatographies. The fractions were analysed by immunoblotting (see below) and the purity of the protein preparations in the positive fractions was controlled by SDS-PAGE and silver staining.

\section{Antiviral assay}

Antiviral activity was measured in bovine Madin-Darby bovine kidney (MDBK) cells, challenged with vesicular stomatitis virus as described by La Bonnardière and Laude (1981). A laboratory reference IFN- $\alpha$ was included in each assay. This reference IFN had been calibrated to $1000 \mathrm{iu} \mathrm{ml}^{-1}$, by comparison on the same MDBK cells with standard human leukocyte IFN (Ga23-902-530, National Institute of Health, Bethesda). Titres were then expressed in iu $\mathrm{ml}^{-1}$.

\section{Immunoblotting}

Aliquots of fractions positive for antiviral activity were analysed by SDS-PAGE followed by western immunoblotting. The proteins were electroblotted onto nitrocellulose membranes (0.1 mm pore size) (Schleicher and Schuell, Ecquevilly) and immunostained with a rabbit anti-ovine IFN- $\tau$ antiserum (Charpigny et al., 1988) using goat horseradish peroxidase-conjugated anti-rabbit $\operatorname{IgG}$ and an enhanced chemiluminescent (ECL) detection system according to the manufacturer's instructions (Amersham, Les Ulis). Non-immune rabbit serum was used as a negative control.

\section{Determination of $N$-terminal amino acid sequences}

Sequences of purified goat trophoblast proteins (cTP) were checked by micro-sequencing using a Perkin Elmer model Procise 494-610A sequencer with methods recommended by the manufacturer (Perkin Elmer, Roissy). Before sequencing, the cysteine residues were derivatized with 4-vinylpyridine. 
Proteins were dissolved in $40 \mathrm{ml} 100 \mathrm{mmol}$ Tris $-\mathrm{HCl} \mathrm{l}^{-1}$, $\mathrm{pH} 8.4$ containing $6 \mathrm{~mol}$ guanidine- $\mathrm{HCl} \mathrm{l}^{-1}$ and $20 \mathrm{mmol}$ dithiothreitol $1^{-1}$. The solution was incubated in the dark under helium for $1 \mathrm{~h} ; 2 \mathrm{ml}$ of 4-vinylpyridine was then added and the mixture was incubated in identical conditions for an additional $\mathrm{Ih}$. Proteins were immediately desalted by chromatography on a short reverse phase column.

\section{Defermination of glycosylation by lectin blotting}

Purified proteins (30 ng each) were vacuum blotted onto a polyvinylidene fluoride (PVDF) transfer membrane (NEN, Boston, MA) in a slot blot chamber. After drying, membranes were incubated overnight at $4^{\circ} \mathrm{C}$ in incubation buffer $(0.05 \mathrm{~mol}$ Tris- $\mathrm{HCl} \mathrm{^{-1 }}$, pH 7.5 containing $0.15 \mathrm{~mol} \mathrm{NaCl} \mathrm{l} l^{-1}, 0.01 \%$ $(\mathrm{v} / \mathrm{v})$ Tween-20 and $2 \%(\mathrm{w} / \mathrm{v}) \mathrm{BSA})$. Lectin binding was performed in incubation buffer containing $\mathrm{I} \mu \mathrm{g}$ biotinylated Concanavalin $\mathrm{A} \mathrm{ml}^{-1}$ (Con $\mathrm{A}$ ), wheat germ agglutinin (WGA) or Dolichos biflorus agglutinin (DBA) (Pierce, Rockford, IL) in the presence or absence of their respective competitive sugars (0.5 mol D-mannose I- ${ }^{-1}, 0.5 \mathrm{~mol} N$-acetyl glucosamine $\mathrm{l}^{-1}$ or $0.1 \mathrm{~mol} \mathrm{~N}$-acetyl galactosamine $\mathrm{l}^{-1}$, respectively). Membranes were incubated in lectin solutions for $1 \mathrm{~h}$ at room temperature on a rocking platform. After four washes (10 min each), lectins bound to blotted proteins were detected with horseradish peroxidase-conjugated steptavidin followed by ECL procedures (see above).

\section{Antisera production}

Rabbit antisera were made for the two major forms (cTP1 and CTP3) of cIFN- $\tau$. Purified proteins ( $40 \mathrm{mg}$ each) were emulsified in Freund's complete adjuvant and injected s.c. at multiple sites. Initial booster injections with $25 \mathrm{mg}$ protein in incomplete Freund's adjuvant were given 3 weeks after the first injection. Subsequent booster injections were given at 1 month intervals. The rabbits were bled from the ear 3 months after the initial immunization. The specificity of each antiserum was tested by immunoblots (see above) against the immunizing antigens and day 17 conceptus culture media. Preimmune rabbit sera were used as a negative control.

\section{Analysis of uterine flushings}

Uterine flushings were collected from slaughtered goats at different days after mating or after oestrus (see above). Flushings were concentrated and dialysed (molecular mass cut-off $3 \mathrm{kDa}$ ) and the protein contents were assayed by the modified method of Lowry (Peterson, 1977). Uterine proteins (20 mg per sample) from day 13 to day 21 pregnant and day 17 cyclic goats were separated by SDS-PAGE and analysed by immunoblotting with rabbit anti-cIFN- $\tau$ sera and ECL detection as described above.

\section{Immunohistochemistry}

Indirect immunohistochemistry was performed using a silver-enhanced immunogold kit (Aurion, Wageningen, NL). The whole procedure was performed at room temperature.
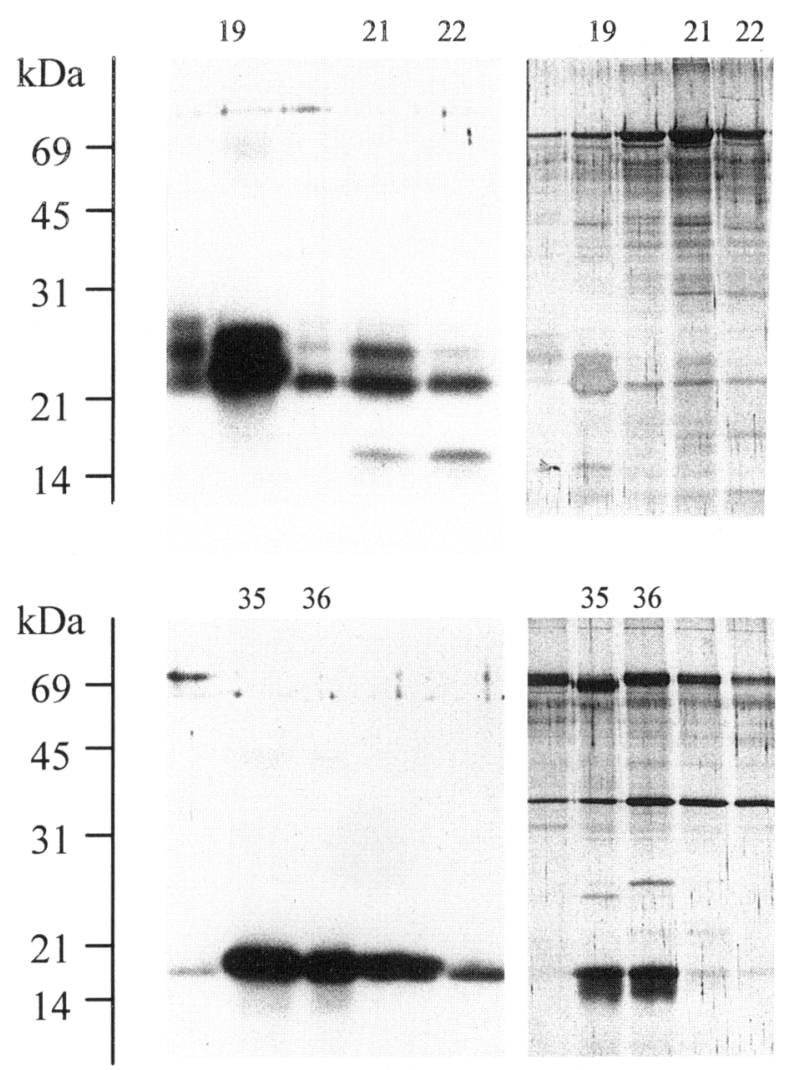

Fig. 2. Immunoblotting with anti-ovine interferon- $\tau$ serum (left panels) and silver staining (right panels) of proteins in the eluted fractions that presented a positive antiviral activity after anionexchange chromatography. Numbers of elution position are indicated above the gels.

Tissue sections were deparaffinized in xylene, rehydrated and incubated with normal goat serum for $1 \mathrm{~h}$ to block nonspecific binding. The sections were then blotted and incubated for $1 \mathrm{~h}$ with 1:100 anti-cTP1 or anti-cTP3 antisera diluted in PBS-0.1\% Aurion BSA-c. Preimmune rabbit serum was used as a negative control. Sections were rinsed in PBS $-0.2 \%(\mathrm{w} / \mathrm{v}) \mathrm{BSA}$ and incubated with goat ultra small immunogold conjugated antirabbit IgG for $2 \mathrm{~h}$. After three washes in PBS- $0.2 \%(\mathrm{w} / \mathrm{v}) \mathrm{BSA}$, the sections were rinsed in PBS and post-fixed in $2 \%(\mathrm{v} / \mathrm{v})$ glutaraldehyde for $5 \mathrm{~min}$. After rinsing in PBS and distilled water, immunogold conjugates were silver enhanced with Aurion R-Gent for $25 \mathrm{~min}$. The tissues were counterstained with $0.1 \%(\mathrm{w} / \mathrm{v})$ Toluidine blue. The sections were observed under brightfield or epi-polarized light on a Reichert microscope.

\section{Results}

\section{Purification of cIFN- $\tau$}

Fractionation of conceptus culture media by anion-exchange DEAE chromatography gave a complex pattern of proteins (Fig. 1). A high antiviral activity was found in two pools of fractions with different retention times (Fig. 1). Peak activity corresponded to fractions 19 and 35. After western blotting, 


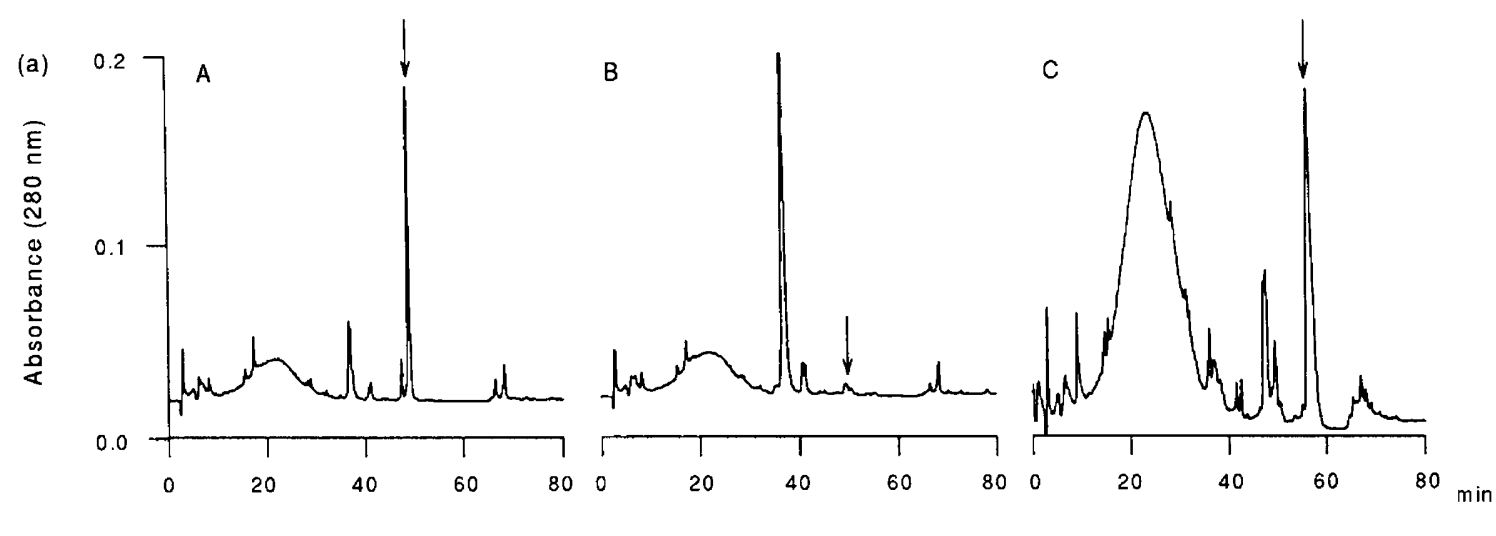

(b)
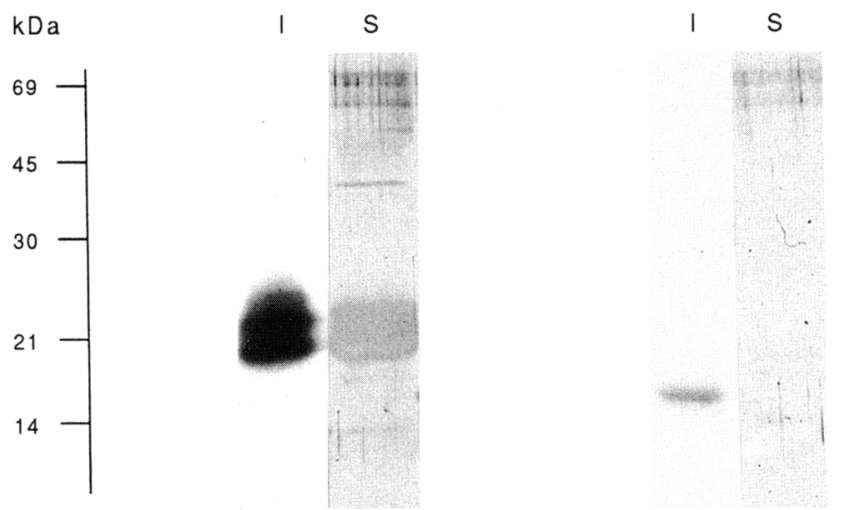

Fig. 3. (a) Elution profiles after reverse-phase chromatography of the three major immunopositive fractions $19,21-22$ and 35 (A, B, C, respectively) from anion-exchange chromatography (a). Arrows indicate the elution position of proteins analysed in (b) by immunoblotting with anti-ovine interferon- $\tau$ (I) and by SDS-PAGE silver staining (S).

these two fractions contained proteins immunologically related to ovine IFN- $\tau$ (Fig. 2). Fraction 19 presented a doublet of proteins with molecular masses of $22-24 \mathrm{kDa}$ and the slowest eluting fraction (number 35) corresponded to a single immunopositive protein with molecular mass $17 \mathrm{kDa}$. Fractions 21 and 22 contained traces of the $22-24 \mathrm{kDa}$ protein and a single protein in the $17 \mathrm{kDa}$ region (Fig. 2). Since the two $17 \mathrm{kDa}$ proteins behaved differently in DEAE chromatography, they were considered as distinct proteins. For clarity these three proteins will be referred to as cTP1 $(22-24 \mathrm{kDa})$, cTP2 $(17 \mathrm{kDa})$ and $\mathrm{CTP} 3(17 \mathrm{kDa})$, numbered in order of elution. After silver staining, both CTP1 and CTP 3 stained intensely whereas CTP2 was barely detectable. However, all three fractions contained contaminating proteins (Fig. 2) which justified a second purification step by reverse phase chromatography. Pools of fractions containing CTP1 or CTP3 gave single major peaks at $280 \mathrm{~nm}$ with retention times of 48.7 and $56.5 \mathrm{~min}$, respectively (Fig. 3). The respective fractions contained proteins that crossreacted with the anti-ovine IFN- $\tau$ and had apparent molecular masses of $22-24$ and $17 \mathrm{kDa}$, respectively (Fig. 3). Both preparations appeared free of contaminating proteins after SDS-PAGE and silver staining (Fig. 3). The protein complex of $22-24 \mathrm{kDa}$ constituting CTP 1 was undissociable under our conditions. Reverse-phase chromatography of DEAE fractions 21-22 showed two minor peaks containing immunopositive proteins (Fig. 3). Two of these proteins corresponded to traces of CTP1 (not shown) and one, eluting at $50.4 \mathrm{~min}$, to cTP2, which was poorly silver stained
(Fig. 3). From a purification protocol with $10 \mathrm{mg}$ of total conceptus proteins released in culture $104 \mu \mathrm{g}$ cTP1, $10 \mu \mathrm{g}$ CTP2 and $85 \mu \mathrm{g}$ cTP 3 were obtained. Thus, only CTP1 and CTP3 were purified in sufficient amounts to allow further study.

\section{$N$-terminal amino acid sequences of purified cIFN- $\tau$}

The amino acid sequences of purified CTP 1 and CTP 3 were determined for the 40 first $\mathrm{N}$-terminal amino acids (Fig. 4). The two proteins presented strict homology (100\%). Amino acids that are conserved in most IFN- $\alpha$ were present in the molecules. Conserved cysteines were detected at position 1 and 29 , leucines at positions $3,9,15,17$ and 18, methionine at position 21 and arginine at position 23 . Amino acid sequences of CTP1 and CTP3 were compared with the cDNA-deduced amino acid sequences of goat IFN- $\tau$ (Leaman and Roberts, 1992), the protein sequence of oIFN- $\tau$ (Charpigny et al., 1988), the cDNA-deduced amino acid sequence of bovine IFN- $\tau$ (Imakawa et al., 1989) or bovine IFN- $\omega$ (Capon et al., 1985). The best match was observed with goat and ovine IFN- $\tau(97 \%$ and $95 \%$, respectively). A lower score was obtained with bovine IFN- $\tau(85 \%)$ and, when compared with the sequence of bovine IFN- $\omega$, the percentage homology was even lower $(60 \%)$.

\section{Antiviral activity of purified cIFN- $\tau$}

When tested on MDBK cells, both purified proteins showed a protective effect against vesicular stomatitis virus (VSV) 


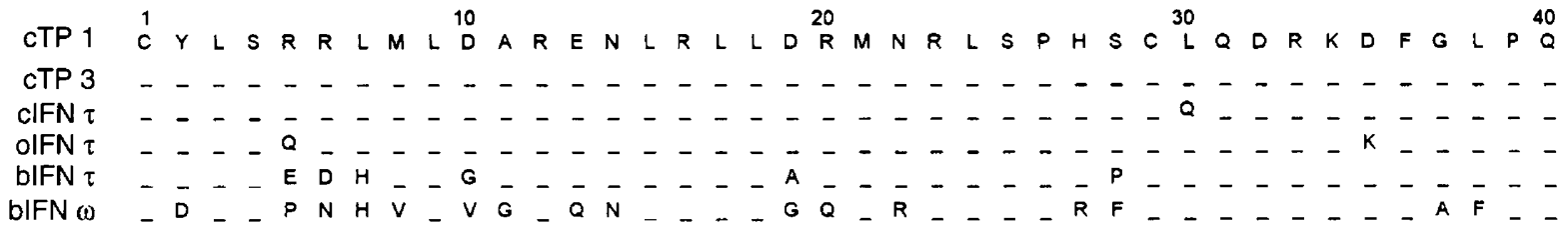

Fig. 4. Comparison of the 40 amino acid N-terminal sequences of purified goat inteferon- $\tau$ (cTP1, cTP3) with the cDNA deduced amino acid sequence of goat interferon- $\tau$ (cIFN- $\tau$ ) (Leaman and Roberts, 1992), with the sequences of ovine (Charpigny et al., 1988), bovine interferon- $\tau$ (Stewart et al., 1987) and bovine interferon- $\omega$ (Capon et al., 1985). Only the divergent amino acids are indicated.

cTP1

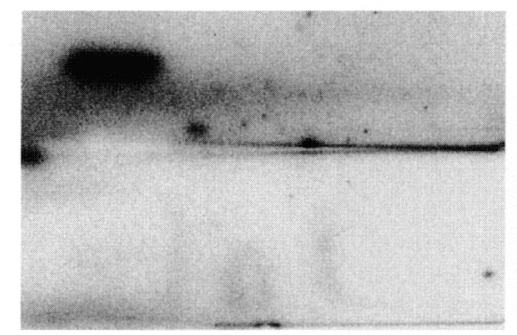

DBA
cTP1

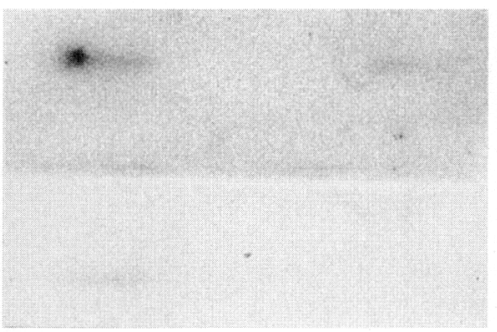

ConA
cTP1

cTP3

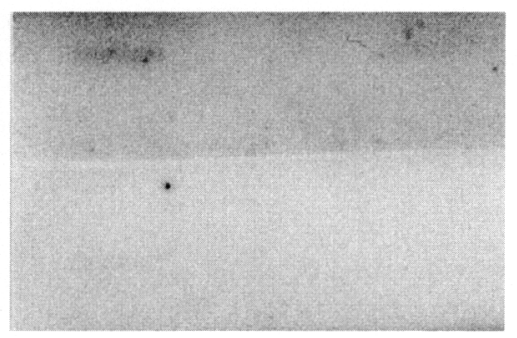

WGA

Fig. 5. Lectin binding on slot blots of purified goat interferon- $\tau$ (cTP1, cTP3). Each membrane was incubated with (a) $1 \mu \mathrm{g} \mathrm{ml}^{-1}$ biotinylated-Dolichos biflorus agglutinin (DBA), -concanavalin A (con A) or -wheat germ agglutinin (WGA) or (b) with a mixture of each lectin and its respective competitive sugar ( $\mathrm{N}$-acetylgalactosamine, $\alpha \mathrm{D}$-mannose and $\mathrm{N}$-acetylglucosamine, respectively, as negative controls.

infection. The purified proteins, CTP1 and cTP3, attained a specific activity of $2 \times 10^{8}$ iu $\mathrm{mg}^{-1}$ protein and $8 \times 10^{8}$ iu $\mathrm{mg}^{-1}$ protein, respectively.

\section{Determination of glycosylation of cIFN- $\tau$}

Positive lectin binding was obtained on CTPI with all three lectins used, whereas no labelling was observed on cTP3 (Fig. 5). Binding of DBA and WGA was inhibited by addition of their competitive sugars ( $N$-acetylgalactosamine and $\mathrm{N}$-acetylglucosamine) to the incubation buffer. Inhibition of ConA binding was incomplete with $0.5 \mathrm{~mol}$ mannose $1^{-1}$.

Specificity of the polyclonal rabbit antisera against cIFN- $\tau$ isoforms

The polyclonal rabbit antisera against $\mathrm{CTP} 1$ and $\mathrm{CTP} 3$ crossreacted with pure samples of CTP1 or CTP3 (Fig. 6). With the antiserum against cTP1, two major bands (molecular mass $22 \mathrm{kDa}$ and $17 \mathrm{kDa}$ ) and a minor band (molecular mass $24 \mathrm{kDa}$ ) were obtained on protein blotting from conceptus culture media, whereas the anti-cTP3 antiserum presented a greater affinity for the $17 \mathrm{kDa}$ protein (Fig. 6). Blots incubated with pre-immune sera were negative.

\section{Time course of cIFN- $\tau$ secretion in vivo}

The protein content in uterine flushings from day 13-21 pregnant goats and from day 17 cyclic goats was analysed by immunoblotting with the antisera raised against CTP1 or CTP3. Since no differences were noticed between the two antisera, only the results obtained with the anti-cTP1 serum are

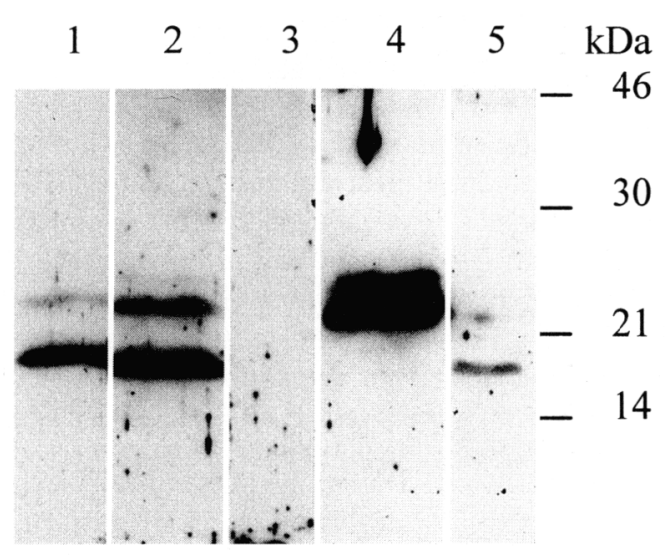

Fig. 6. Immunodetection of goat interferon- $\tau$ in day 17 conceptus culture medium with rabbit anti-cTP3 (lane 1), anti-cTP1 (lane 2) sera and normal rabbit serum (lane 3). Pure cTP1 (500 ng) and CTP3 $(300 \mathrm{ng})$ were loaded and detected with anti-cTPI serum as standards (lanes 4 and 5, respectively).

presented here. CTP3 was first detected on day 16, and CTP1 became detectable by day 17 of pregnancy, but cTP 3 remained the major protein present in the uterine flushings. Both proteins were undetectable at day 19 and day 21 of pregnancy (Fig. 7). No uterine proteins from the day 17 cyclic goat crossreacted with the antibodies against CTPs, and the immunoblot incubated with normal rabbit serum was negative (Fig. 7).

\section{Immunohistochemical localization of $c I F N-\tau$}

The cellular distribution of cIFN- $\tau$ was observed during the peri-implantation period from day 10 to day 21 of pregnancy. 


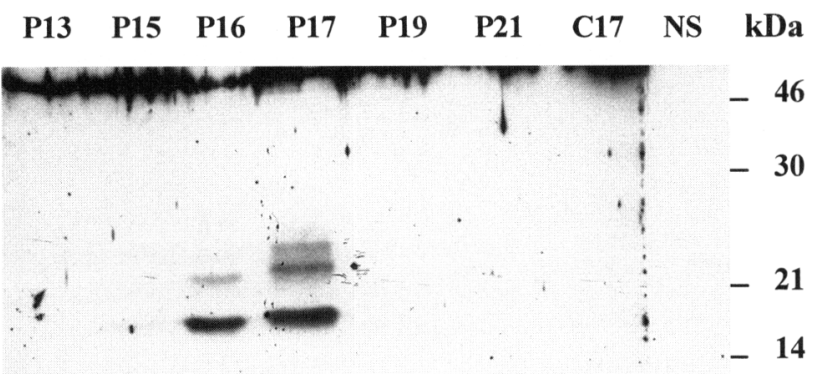

Fig. 7. Immunodetection of goat interferon- $\tau$ in uterine flushings of pregnant $(\mathrm{P})$ and of cyclic $(\mathrm{C})$ goats with rabbit anti-cTPI serum. Uterine flushing from day 17 pregnant goat was run in the control lane detected with normal rabbit serum (NS). All lanes were loaded with $20 \mathrm{mg}$ protein. Days after coitus or after oestrus are shown above the blots.

No immunostaining was observed in spherical day $10(n=3)$ or day 13 conceptuses $(n=2)$. In early elongating day 14 conceptuses $(2-4 \mathrm{~cm}$ in length; $n=4)$, heterogeneous immunostaining was observed in the trophoblastic cells along the conceptus, regardless of which antisera against cIFN- $\tau$ was used. A gradient of labelling was observed, the intensity of the immunostaining increasing from the embryonic area to the more distal trophoblast (Fig. 8). No labelling could be detected in the embryonic cells, in the endoderm, or in the mesoderm of the growing yolk sac (Fig. 8). Sections treated with rabbit non-immune serum were negative (data not shown). In filamentous day 17 conceptuses, the same pattern of immunostaining was observed as for day 14 conceptuses, in that the abembryonic trophoblast presented a strong labelling whereas the embryonic area was negative (Fig. 9). Trophoblast from implanting day 18 conceptuses showed only a weak residual labelling in scattered portions of tissues, but most of the trophoblastic cells were negative (Fig. 9). The binucleate cells that appeared at this stage were not immunostained. No positive staining could be observed on sections of tissues from later stages of pregnancy (data not shown).

\section{Discussion}

In the present study, three proteins (cTP1, cTP2 and cTP3) produced by goat day 17 conceptuses and immunorelated to ovine IFN- $\tau$ are described. The three proteins isolated differ in their molecular masses (22-24 and $17 \mathrm{kDa})$ and charges since they behaved differently in anion-exchange chromatography. It is likely that these products represent the goat trophoblast protein-1 complex (cTP-1) described by Gnatek et al. (1989). The fact that CTP3 was the latest eluting product in the salt gradient in anion-exchange chromatography indicates that it corresponds to the most acidic protein (isoelectric point 5.2) described by these authors. The three proteins were not produced by the conceptus in the same proportion. The major proteins present in culture media were cTP3 and the $22 \mathrm{kDa}$ form of CTP1. Purification of these proteins was achieved by a two-step HPLC procedure from conceptus culture media. Only CTP1 and CTP3 were released in sufficiently large amounts to allow further characterization and production of specific
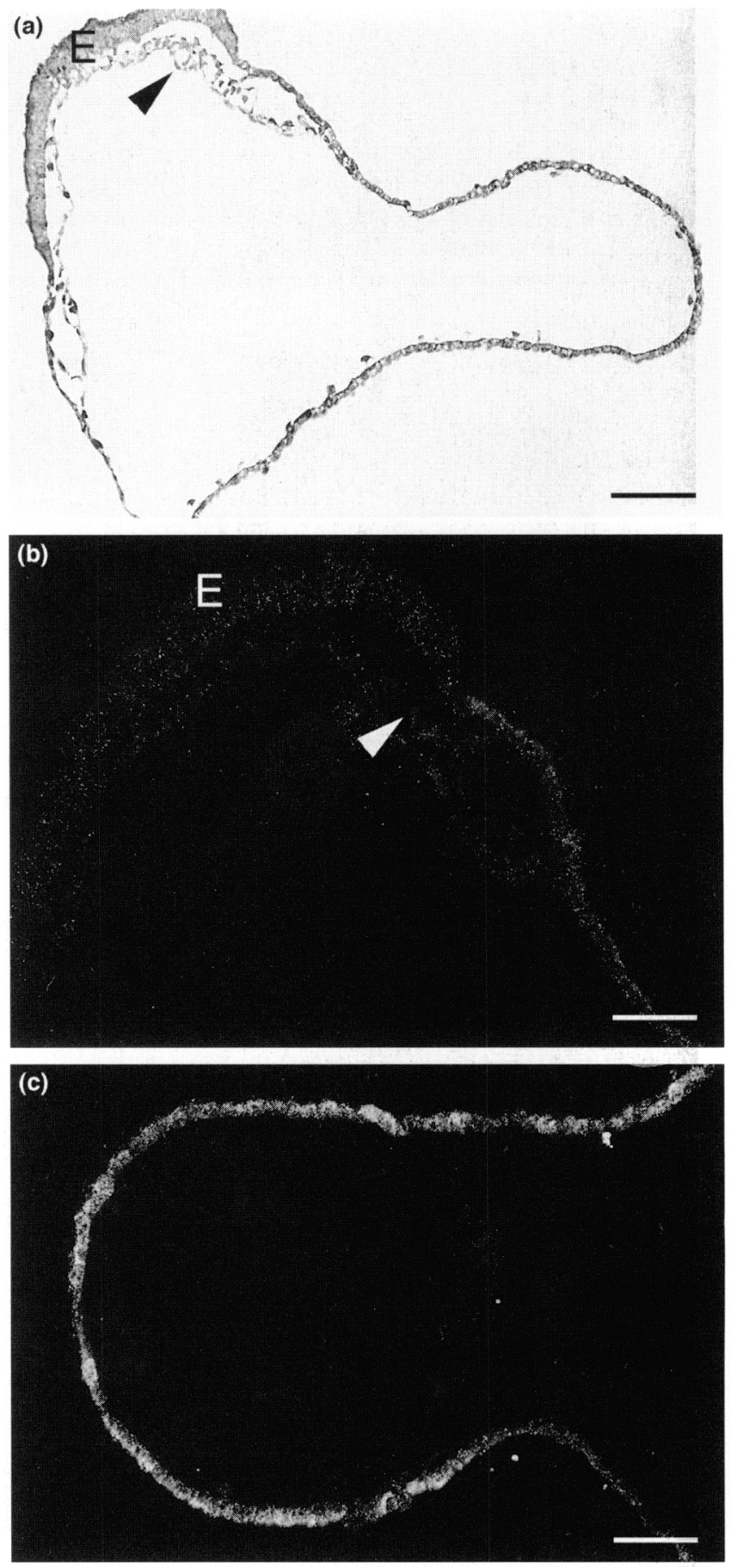

Fig. 8. Cellular localization of goat interferon- $\tau$ in day 14 conceptus by immunogold histochemistry with rabbit anti-cTP1 serum. (a) Brightfield low power view of the section (scale bar represents $100 \mathrm{~mm}$ ); (b) embryonic pole and (c) abembryonic pole observed by epi-illumination (scale bars represent $40 \mathrm{~mm}$ ). E: embryo; arrowheads, yolk sac membranes.

polyclonal antisera. On the basis of their crossreactivity with anti-oIFN- $\tau$ antiserum, their amino acid sequence homologies with previously described trophoblast interferons, and their antiviral activities, it is likely that these two proteins belong to the IFN- $\tau$ family which is characteristic of the ruminant 


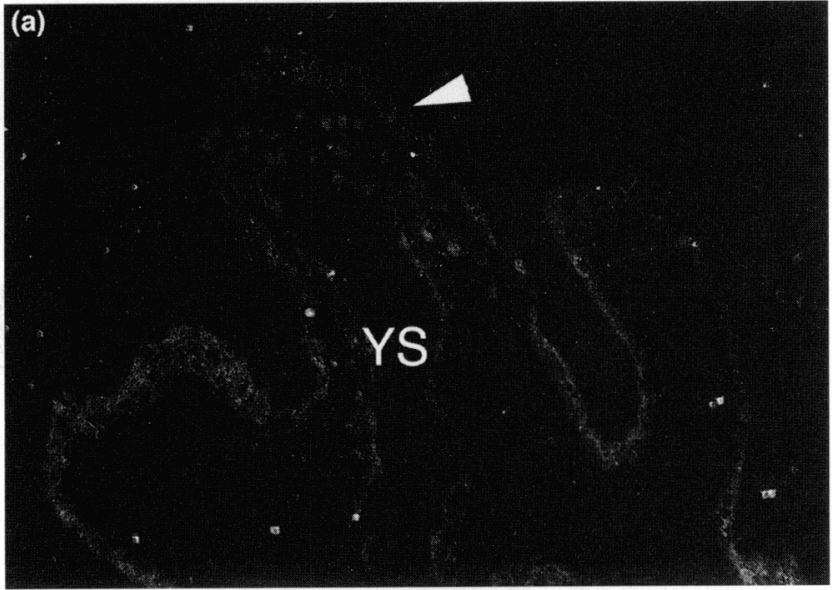

(b)
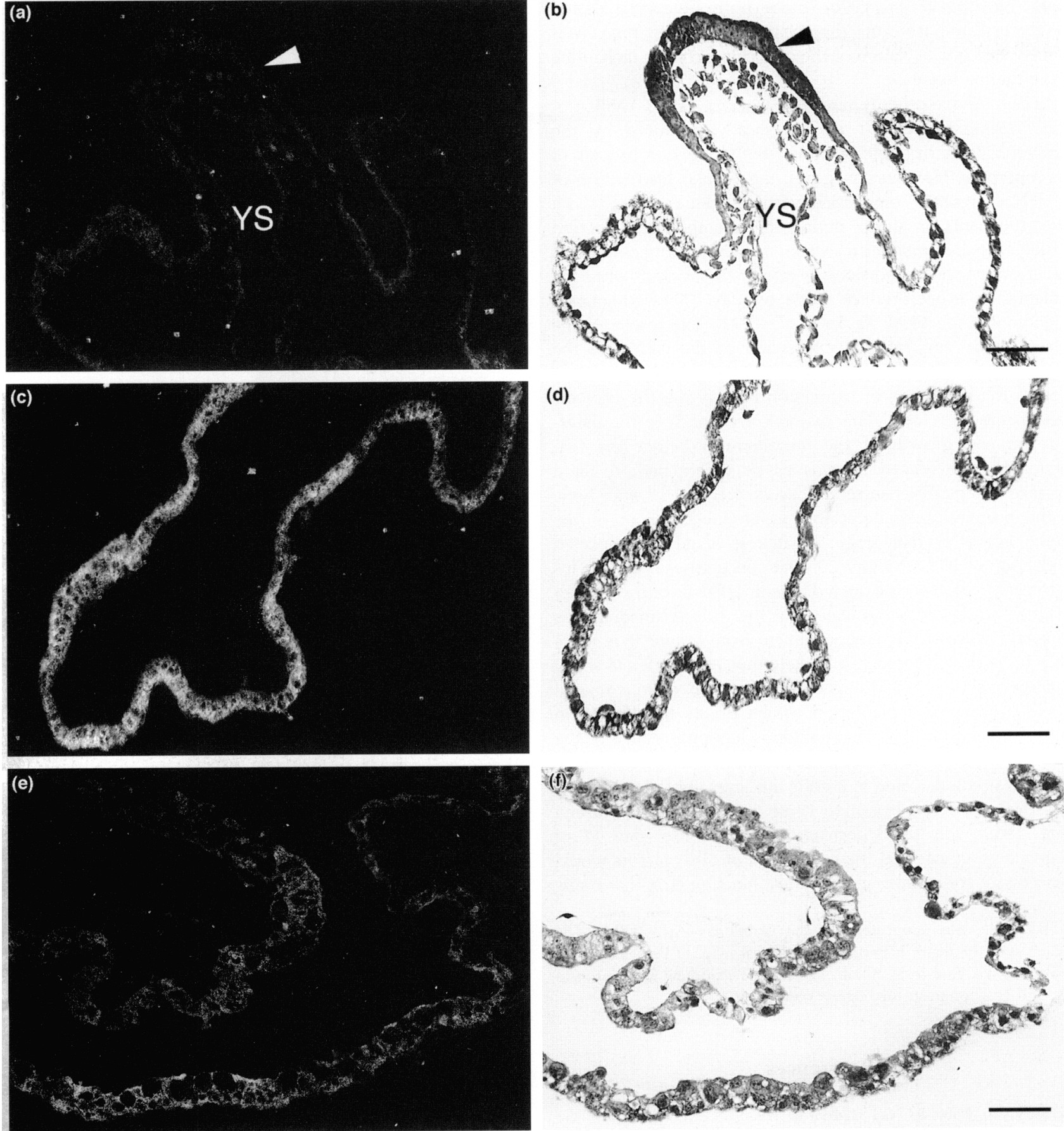

Fig. 9. Cellular localization of goat interferon- $\tau$ in day $17(\mathrm{a}-\mathrm{d})$ and day $18(\mathrm{e}, \mathrm{f})$ conceptuses by immunogold histochemistry with a rabbit anti-cTP1 serum. Epi-illumination ( $a, c, e)$ and corresponding brightfield ( $b, d, f)$ observations. ( $a, b)$ Embryonic area and ( $c$, d) abembryonic pole from the same section. Arrowheads: embryo; YS: yolk sac membranes. Scale bars represent $40 \mathrm{~mm}$.

conceptus (Roberts et al, 1992). As shown by lectin binding, the $22-24 \mathrm{kDa}$ protein (cTP1) is the glycosylated isoform of CTP-1, which has been reported by Baumbach et al. (1990). Binding of lectins DBA, WGA and ConA indicates the presence of $\mathrm{N}$-acetyl galactosamine, $\mathrm{N}$-acetyl glucosamine and mannose residues in the molecule. Thus, unlike the olFN- $\tau$ which are not glycosylated and the bIFN- $\tau$ which are (Helmer et al., 1988), the cIFN-t are a mixture of both forms. Analysis of the protein contents of uterine flushings from day 13 to day 21 pregnant goats showed that the non-glycosylated protein (cTP3) was secreted before and in higher amounts than the glycosylated isoform (CTPI), as has been reported in analyses of conceptus culture media (Gnatek et al., 1989; Newton et al., 1996). The specific role of the glycosylated protein is unclear since intrauterine injections of nonglycosylated recombinant olFN- $\tau$ results in the maintenance of luteal function in cyclic 
goats (Newton et al., 1996). Since both glycosylated and nonglycosylated isoforms disappear at the same time, it is unlikely that glycosylation of the molecule increases its half-life in the uterine lumen.

As observed in other ruminants (Farin et al., 1990; Guillomot et al., 1990), the cIFN- $\tau$ are specifically produced by the extra-embryonic trophoblast during the elongation process of the conceptus. However, in goats, the cellular distribution of the IFN- $\tau$ presents some discrepancies when compared with other ruminants. In sheep, during the preimplantation period the IFN- $\tau$ is uniformally present in the whole trophoblast and the cessation of expression is closely associated with the implantation process which starts by day 15 of pregnancy (Guillomot et al., 1990; Xavier et al., 1991). The results of the present study suggest that expression of the cIFN- $\tau$ in the trophoblastic cells surrounding the embryo is very low, since even at the beginning of expression by day 14, the proteins were barely detectable. This period corresponds to the differentiation and growth of the mesoderm. Whether the two phenomena are related remains to be determined. A rapid decrease of the cIFN- $\tau$ secretion occurs after day 17 since none of the proteins were detectable in uterine fluids or in the trophoblast after that stage. Gnatek et al. (1989) reported production of IFN- $\tau$ by day 20 goat conceptuses in vitro. This discrepancy may result from a different turnover of the protein in vitro, where it accumulates in the culture medium, as compared with in the uterine lumen, from where it is more likely to be cleared rapidly. It is likely that, as reported in sheep (Guillomot et al., 1990), the end of IFN- $\tau$ production is related to the process of implantation, which occurs by day 18 in goats. The end of cIFN- $\tau$ expression is less progressive or the half-life of the proteins is shorter than for the olFN- $\tau$ since oIFN- $\tau$ was still detected in uterine flushings until day 24 , long after the expression began to cease around day 15 (Kazemi et al., 1988). The rapid decrease of cIFN- $\tau$ after day 17 of pregnancy suggests that the production of other factors would be necessary for maintenance of luteal function after that stage.

This work was supported by the Cytokines AIP, INRA. The authors wish to thank J. Bertin for technical help, L. Pessemesse for performing antiviral tests, $B$. Nicolas and $P$. Dieudonné for photography, and E. Thompson for English correction.

\section{References}

Baumbach GA, Duby RT and Godkin ID (1990) N-glycosylated and unglycosylated forms of caprine trophoblast protein-1 are secreted by preimplantation goat conceptuses Biochemical and Biophysical Research Communications 172 16-21
Bazer FW, Spencer TE and Ott TL (1996) Placental interferons American Journal of Reproductive Immunology 35 297-308

Capon DJ, Shepard HM and Goeddel DV (1985) Two distinct families of human and bovine interferon- $\alpha$ genes are coordinately expressed and encodes functional polypeptides Molecular and Cellular Biology 5 768-779

Charlier M, Hue D, Martal J and Gaye P (1989) Cloning and expression of cDNA encoding ovine trophoblastin: its identity with a class-II alpha interferon Gene 77 341-348

Charpigny G, Reinaud P, Huet JC, Guillomot M, Charlier M, Pernollet JC and Martal J (1988) High homology between a trophoblastic protein (trophoblastin) isolated from ovine embryo and $\alpha$-interferons FEBS letters $\mathbf{2 2 8}$ $12-16$

Farin CE, Imakawa K, Hansen TR, McDonnell JJ, Murphy CN, Farin PW and Roberts RM (1990) Expression of trophoblastic interferon genes in sheep and cattle Biology of Reproduction $\mathbf{4 3}$ 210-218

Gnatek GG, Smith LD, Duby RT and Godkin JD (1989) Maternal recognition of pregnancy in the goat: effects of conceptus removal on interoestrus intervals and characterization of conceptus protein production during early pregnancy Biology of Reproduction 41 655-663

Guillomot M, Michel C, Gaye P, Charlier N, Trojan J and Martal J (1990) Cellular localization of an embryonic interferon, ovine trophoblastin and its mRNA in sheep embryos during early pregnancy Biology of the Cell 68 205-211

Helmer SD, Hansen PJ and Thatcher WW (1988) Differential glycosylation of the components of bovine trophoblast protein-I complex Molecular and Cellular Endocrinology 58 103-107

Homeida AM and Al Afaleq AI (1994) Delayed luteolysis and suppression of testosterone secretion after recombinant ovine interferon treatment in goats (Capra hircus) Journal of Reproduction and Fertility $102301-304$

Imakawa K, Hansen TR, Malathy PV, Anthony RV, Polites HG, Marotti KR and Roberts RM (1989) Molecular cloning and characterization of complementary deoxyribonucleic acids corresponding to bovine trophoblast protein- 1 : a comparison with ovine trophoblast protein- 1 and bovine interferon- $\alpha$ II Molecular Endocrinology 3 127-139

Kazemi M, Malathy PV, Keisler DH and Roberts RM (1988) Ovine trophoblast protein-1 and bovine trophoblast protein- 1 are present as specific components of uterine flushings of pregnant ewes and cows Biology of Reproduction 39 457-463

La Bonnardière $C$ and Laude $H$ (1981) High interferon titer in newborn pig intestine during experimentally induced viral enteritis Infectious Immunology 32 28-31

Leaman DW and Roberts RM (1992) Genes for the trophoblast interferons in sheep, goat, and musk ox and distribution of related genes among mammals Journal of Interferon Research 12 1-11

Newton GR, Ott TL, Woldesenbet S, Shelton AH and Bazer FW (1996) Biochemical and immunological properties of related small ruminants trophoblast interferons Theriogenology 46 703-716

Peterson GL (1977) A simplification of a protein assay method of Lowry et al. which is more generally applicable Analytical Biochemistry 83 346-356

Roberts RM, Cross JC and Leaman DW (1992) Interferons as hormones of pregnancy Endocrine Reviews 13 432-452

Stewart HJ (1990) Trophoblastic factors and the maternal recognition of pregnancy in sheep and cattle Journal of Developmental Physiology 14 115-123

Xavier F, Guillomot M, Charlier M, Martal J and Gaye P (1991) Co-expression of the proto-oncogene fos ( $c-f o s)$ and an embryonic interferon (ovine trophoblastin) by sheep conceptuses during implantation Biology of the Cell $\mathbf{7 3}$ 27-33 